\title{
Influence of Workstation and Work Posture Ergonomics on Job Satisfaction of Librarians in the Federal and State University Libraries in Southern Nigeria
}

\author{
Ikonne, Chinyere N. \\ Department of Information Resources Management \\ Babcock University
}

\begin{abstract}
This study investigated the influence of workstation and work posture ergonomics on the job satisfaction of librarians in the Federal and State University libraries in Southern Nigeria. The study adopted the survey research design. The total enumeration technique was used to include the 500 librarians from the 37 Federal and State University libraries in Southern Nigeria. Descriptive statistics was used to analyze the data collected. The findings revealed that there was a positive relationship between ergonomics (suitability of workstation and equipment and work posture designs) and job satisfaction. It was, therefore, recommended that ergonomic measures that would involve the set-up of adequate and healthy workstation equipment designs, which would allow the users to adopt optimal working postures suitable for a greater job satisfaction, be implemented in the Nigerian University libraries.
\end{abstract}

Key Words: Ergonomics, job satisfaction, workstation and equipment design, work posture ergonomics, librarians

\section{Introduction}

Job satisfaction is a frequently studied subject as evidenced in work and organizational literature. This stems from the fact that experts believe that the level of job satisfaction can affect labor market behavior. Low rate or lack of job satisfaction, according to Flanagan and Flanagan (2002), has been considered as one of the most important evidence of the worsening and deterioration work conditions of an organization as it could lead to quitting of a job, (Gazioglu and Tansel, 2002).

Ergonomics is the scientific discipline that is concerned with understanding of the interactions among humans and other elements of a system. It applies theory, principles, data and methods to design, so as to improve human well-being and overall system performance (International Ergonomics Association (IEA) (2000). Ergonomics aims at designing the workplace so that it will fit the needs and physical capabilities of employees, instead of physically forcing the worker's body to fit the job, (Ghosh et al, 2011). Ergonomic factors that can elicit job satisfaction could be derived from a wide range of issues that emanate from the workplace. For instance, if work environment is poorly designed, it could hinder or slow down the employee's performance in the workspace, and this could eventually lead to frustration which, in turn, affects job satisfaction.

The library is one of the key units of any educational institution. As a result, it plays a vital role in ensuring that the University fulfills its academic obligations towards the library users. Currently, many libraries have gone hi-tech as they strive to move with the pace of technology. For instance, many libraries are now automated and according to Timoteo-Afinidad (2010), works like cataloging and indexing (that were once done manually), are done with computers due to their efficiency, effectiveness, and high productivity. Considering this, librarians need to work in comfortable and healthy designed libraries. In particular, the workstations and equipment designs should be comfortable as they are indispensible to their work. Any uncomfortable and stressful work environment could result in job dissatisfaction, which could equally affect the quality of workers' performance.

\section{Statement of the Problem}

Some organizations and libraries have picked interest in designing their workplace environment through the application of ergonomic measures so as to provide suitable workstation and equipment designs thereby improving job satisfaction. But there are indications which show that the Nigerian University libraries are slow in adopting ergonomic principles in designing these facilities in the libraries. As a result, the library workforce is encountering ergonomic challenges that could influence the achievement of job satisfaction. Therefore, this study examined the influence of workstation design and work posture ergonomics on the job satisfaction of the librarians in the Federal and State University libraries in Southern Nigeria. 


\section{Objective of the study}

The general objective of this study was to examine the relationship between the suitability of workstation and work posture equipment designs on the job satisfaction of librarians in the Federal and State University libraries in Southern Nigeria. The specific objectives were to:

1. determine if the workstation and equipment designs are suitable for the job satisfaction of the librarians in the Federal and State University libraries in Southern Nigeria.

2. determine whether the work posture condition (sitting or standing) of librarians has any influence on their job satisfaction.

\section{Hypotheses}

For the purpose of this study, the author has constructed the following pertinent hypotheses.

Ho1 There is no significant relationship between the suitability of workstation and equipment designs and the job satisfaction of the librarians.

H॰2 There is no significant relationship between the condition of work posture (sitting or standing) of the librarians and their job satisfaction.

\section{Review of Literature}

There is the assumption that, generally, in the workplace, employees who are more satisfied with the physical environment are more likely to produce better work outcomes. Chandrasekar (2011) stated that workplace environment in a majority of the industries is described as unsafe and unhealthy for the fact that there are poorly designed workstations, unsuitable furniture, lack of ventilation, inappropriate lighting, excessive noise, insufficient safety measures in fire emergencies and lack of personal protective equipment. User satisfaction is recognized as an important factor in the success of an organization and is regarded as a key indicator of performance, (Dole and Schroeder, 2001). Lee and Brand (2005) reported that studies reveal that workers who are comfortable with their working environment have the tendency of generating better work. This is because their physical environment positively affects their job perception, attitudes, and job satisfaction.

\section{Workstation Equipment Design}

One of the ergonomic factors that could impact job satisfaction is the design of workstation and equipment. Modern day offices are equipped with computer technology and, as a result, many employees use a computer workstation in the course of their work. The layout of workers' desk, the way the computer is placed, the type of chair, and the space in which workers find themselves, all have influence on ergonomic conditions.

De Croon et al (2005) pointed out that workstation design could result either directly or indirectly in physiological and psychological reactions. Incorrect and poor computer workstation set-ups produce a variety of problems. For one, people may tend to have the feeling of a state of inadequacy of space, low job contentment, induced stress fatigue and, possibly increase in the levels of blood pressure. Secondly, decreased performance and negative health outcomes, like chronic fatigue, burnout and musculoskeletal disorders, according to De Lange, et al (2003) and Tarris et at (2003), could be some of the long term reactions. Workstation design includes computer set-ups, desk, chair, space and layouts. De Croon et al. (2005) noted that depending on how workstation is designed, it could lead either directly or indirectly to physiological and psychological reactions. For instance, ergonomically incorrect and poor computer workstation set-ups could produce a variety of problems in the form of crowding stress (the feeling of inadequacy of space), job satisfaction decrement, occupationally induced fatigue, and probable increase in the levels of blood pressure.

In their study of work related and individual predictors for incident neck pain among office employees working with video display units in Finland et al (2003) discovered that the annual incidence of neck pain, as a result of poor physical work environment and poor placement of the keyboards was $34.4 \%$. Therefore, the set-up of a computer workstation should allow the user to adopt optimal working postures and at the same time allow the one some freedom of movement. In addition, the height and density of workstation partitions, the amount and accessibility of file and work storage, and furniture dimensions such as work-surfaces have also been perceived as factors influencing optimal work conditions. These elements of furniture and spatial layout have a powerful effect on individual satisfaction and also on the performance of teams.

In addition, the computer workstation should provide the necessary resources to perform other jobs. This will reduce the repetitive motion stress to the worker while providing a mental stimulus to prevent boredom. According to Fraser (2009), the optimal design and adjustment and use of computer workstations are important measures for the prevention of musculoskeletal injury. The aim should be to create a workplace in which employees can work in neutral condition, and this will eventually lead to minimizing the wear and tear on their bodies. According to Washington State Department of Labor and Industries (2002), if workers are expected to adapt to a job that exceeds their body's physical limitations, they can become injured. Human Factors and Ergonomics Society of Australia (2006) also posited that employees come in different sizes and shapes and, 
consequently, one of the main elements that need to be adjusted when an employee sits down at a workstation are the chairs, keyboard, mouse, monitor, document holders, and placement of equipment on desk. Based on this, Dempsey, McGorry, and O'Brien (2004) suggested that workstation design from an ergonomics perspective can effectively enhance productivity and minimize stress through the interaction between the various system components. Miller's (2007) survey of 500 workers revealed that office workers ranked "having an office that is comfortable to work in" as the most highly valued workstation attribute across all worker types.

\section{Work Posture}

Workstation designs significantly affect working posture which, in turn, contributes to physical symptoms. Work posture (sitting, standing or bending, twisting, carry, lifting) has been identified as one of the most important factors when considering workstation design, according to WorkSafeNB (2010). For one, the chair is considered to be one the most important part of the office workstation. It must fit the worker as well as suit the tasks that the worker is doing. For example, it has been observed that poor chairs and/or bad posture can cause lower back strain, and a chair that is too high can cause circulation loss in legs and feet. One style of chair may not be suitable for every worker, (Office Ergonomics Handbook, 2008). Therefore, Miles (2000) opined that investing in ergonomic tables and chairs for workers could additionally yield a five (5) month payback in terms of increased productivity. Further, it is observed that regular variation between sitting, standing and walking is vital for back injury management and prevention (Fraser, 2009).

Adeyemi (2010) stated in her study that Nigerian academic library workers face a wide variety of ergonomic problems that are manifested in the forms of headache, tension and stress. She further emphasized that improper sitting and positioning of the computer monitors as well as lifting and carrying are some of the problems they experience.

Prolonged standing in the workplace, according to Lafond et al (2009) has been linked to an onset of work-related musculoskeletal disorders and, in particular, with lower back pain. Ansari et al (2013) reported on the study and justification of body postures of workers working in SSI in India, found evidence of musculoskeletal disorders among the workers as a result of prolonged same postures. According to Zander, King, and Ezenwa (2004), prolonged standing transfers the load of upper body to the lower parts which, in turn, results in lower back pain. They further note that the American Podiatric Association reports that $83 \%$ of industrial workers in the United States experience foot or lower leg pain and discomfort as a result of prolonged standing. O'Neil (2005) also pointed out that Occupational health statistics from the United Kingdom estimates that hundreds of thousands of workers have suffered from injuries due to prolonged standing and this has resulted in over two (2) million days sick leave a year.

\section{Methodology}

The survey research design was employed through the use of a structured questionnaire. Total enumeration was used to survey the opinion of the population which was made up of all the 500 librarians working in the 37 Federal and State University libraries in Southern Nigeria. The instrument was validated by some professors who are experts in this subject matter. A pre-test of the questionnaire was conducted at two university libraries after which an overall Cronbach alpha reliability coefficient of 0.70 was obtained. The option of choices followed the pattern of a 4-point scale: from 1 -Strongly Disagree to 4 - Strongly Agree $(1=$ low and $4=$ high). The data collected were analyzed using descriptive statistics of frequency count, percentage, mean and standard deviation.

Table 1: List of Federal and State Universities/Libraries in the Southern Nigeria

\begin{tabular}{|l|l|l|}
\hline \multicolumn{1}{|c|}{ State } & \multicolumn{1}{|c|}{ Federal University Library } & \multicolumn{1}{c|}{ State University Library } \\
\hline Abia & Micheal Okpara University of Agiculture, Umudike & Abia State University,Uturu \\
\hline Akwa Ibom & University Of Uyo, Uyo & Akwa -Ibom State University Of Technology, Uyo \\
\hline Anambra & Nnamdi Azikiwe University, Awka & Anambra State University of Science and Technology, Uli \\
\hline Bayelsa & Niger Delta University,Yenagoa & Federal University, Otuoke, Bayelsa \\
\hline Cross River & University of Calabar, Calabar & Cross River State University and Technology, Calabar \\
\hline Delta & Federal University of Petroleum Resources, Effurun & Delta State University, Abraka \\
\hline Ebonyi & Federal University, Ndufu-Alike & Ebonyi State University, Abakaliki \\
\hline Edo & University of Benin, Benin City & Ambrose Alli University, Ekpoma \\
\hline Ekiti & Federal University, Oye-Ekiti & Ekiti State University, Ado Ekiti \\
\hline Enugu & University of Nigeria, Nsukka & Enugu State University of Science and Technology, Enugu \\
\hline Imo & Federal University of Technology, Owerri & Imo State University, Owerri \\
\hline Lagos & University of Lagos & Lagos State University, Lagos \\
\hline \multirow{2}{*}{ Ogun } & Olabisi Onabanjo Universiy, Ago Iwoye & Tai Solarin University of Education, Ijebu-Ode \\
\cline { 2 - 3 } & University of Agriculture, Abeokuta & \\
\hline Ondo & Federal University of Technology, Akure. & Ondo State University of Science and Technology, Okitipupa \\
\cline { 2 - 3 } & & Adekunle Ajasin University, Akungba \\
\hline Osun & Obafemi Awolowo University, Ile-Ife. & Ladoke Akintola University of Technology, Ogbomoso. \\
\hline
\end{tabular}


Influence of Workstation and Work Posture Ergonomics on Job Satisfaction of Librarians in ....

\begin{tabular}{|l|l|l|}
\hline Oyo & University of Ibadan, Ibadan & Osun State University, Oshogbo \\
\hline Rivers & University of Port Harcourt, Port Harcourt & Rivers State University of Science and Technology \\
\hline & \multicolumn{1}{|c|}{$\mathbf{1 8}$} & Ignatius Ajuru University of Education, Rumuolumeni \\
\hline & Overall Total & $\mathbf{1 9}$ \\
\hline
\end{tabular}

Presentation of Findings

Table 2: Demographic characteristics of respondents

\begin{tabular}{|l|l|c|c|}
\hline \multicolumn{2}{|c|}{ Demographic Information } & Study Sample & Percentage \\
\hline Character & \multicolumn{1}{|c|}{ Information } & Frequency & 46.3 \\
\hline \multirow{4}{*}{ Gender } & Male & 163 & 53.7 \\
\cline { 2 - 4 } & Female & 189 & $\mathbf{1 0 0 . 0}$ \\
\cline { 2 - 4 } & Total & $\mathbf{3 5 2}$ & 34.7 \\
\hline \multirow{5}{*}{$\begin{array}{l}\text { Educational } \\
\text { Qualification }\end{array}$} & BLS/BLIS & 122 & 1.1 \\
\cline { 2 - 4 } & BIRM & 4 & 40.3 \\
\cline { 2 - 4 } & MLS/MLIS & 142 & 3.7 \\
\cline { 2 - 4 } & MSCInf & 13 & 3 \\
\cline { 2 - 4 } & MIRM & 1 & 2.3 \\
\cline { 2 - 4 } & PhD & 8 & $\mathbf{1 0 0 . 0}$ \\
\cline { 2 - 4 } & Others & $\mathbf{3 5 2}$ & \\
\cline { 2 - 4 } & Total & & \\
\hline
\end{tabular}

Table 2 reveals the distribution of respondents based on their gender as well as their educational qualification. The table revealed that there were 189 women $(53.7 \%)$ while the male respondents were 163 (46.3\%). Regarding educational qualification, the study showed that the major percentage of the respondents (40.3\%) were MLS/MLIS (Masters in Library Science/Masters in Library and Information Science) degree holders while $34.7 \%$ were BLS/BLIS (Bachelor in Library Science/Bachelor in Library and Information Science) holders. About $3.7 \%$ were MSc. Inf (Masters in Science Information) degree holders, 2.3\% were Ph.D holders, while $1.1 \%$ and $.3 \%$ were BIRM (Bachelor in Information Resources Management) and MIRM (Masters in Information Recourses Management) degree holders respectively. About eighteen percent (17.6\%) indicated their education qualification as "others".

Research question 1 asked: What are the ways through which workstation and equipment designs are suitable to the job satisfaction of librarians?

Table 3: Suitability of computer workstation and equipment designs and job satisfaction of the librarians

\begin{tabular}{|c|c|c|c|c|c|c|}
\hline STATEMENT & $\begin{array}{l}\text { SD } \\
(\%)\end{array}$ & $\begin{array}{l}\text { D } \\
(\%)\end{array}$ & $\begin{array}{l}\text { A } \\
(\%)\end{array}$ & $\begin{array}{l}\text { SA } \\
(\%)\end{array}$ & Mean & SD \\
\hline $\begin{array}{l}\text { The height of my worktable is satisfactory in relation to my posture } \\
\text { and viewing }\end{array}$ & $\begin{array}{l}33 \\
(9.4)\end{array}$ & $\begin{array}{l}85 \\
(24.1)\end{array}$ & $\begin{array}{l}193 \\
(54.8)\end{array}$ & $\begin{array}{l}41 \\
(11.6)\end{array}$ & 2.69 & .798 \\
\hline $\begin{array}{l}\text { My workstation is designed to ensure that my wrist and hands do not } \\
\text { rest on sharp or hard edges }\end{array}$ & $\begin{array}{l}37 \\
(10.5)\end{array}$ & $\begin{array}{l}124 \\
(35.2)\end{array}$ & $\begin{array}{l}153 \\
(43.5)\end{array}$ & $\begin{array}{l}38 \\
(10.8)\end{array}$ & 2.55 & .822 \\
\hline My computer workstation design is large enough for my work & $\begin{array}{l}63 \\
(17.9)\end{array}$ & $\begin{array}{l}84 \\
(23.9)\end{array}$ & $\begin{array}{l}157 \\
(44.6)\end{array}$ & $\begin{array}{l}48 \\
(13.6)\end{array}$ & 2.54 & .939 \\
\hline $\begin{array}{l}\text { My computer workstation design is comfortable for my work posture } \\
\text { (sitting/standing) }\end{array}$ & $\begin{array}{l}42 \\
(11.9)\end{array}$ & $\begin{array}{l}112 \\
(31.8) \\
\end{array}$ & $\begin{array}{l}165 \\
(46.9) \\
\end{array}$ & $\begin{array}{l}33 \\
(9.4)\end{array}$ & 2.54 & .823 \\
\hline $\begin{array}{l}\text { I have sufficient room between the top of my thighs and my computer } \\
\text { table }\end{array}$ & $\begin{array}{ll}43 \\
(12.2)\end{array}$ & $\begin{array}{l}112 \\
(31.8)\end{array}$ & $\begin{array}{l}161 \\
(45.7)\end{array}$ & $\begin{array}{l}36 \\
(10.2)\end{array}$ & 2.54 & .836 \\
\hline $\begin{array}{l}\text { The quality of my workstation equipment is good enough for me to } \\
\text { work effectively }\end{array}$ & $\begin{array}{l}35 \\
(9.9)\end{array}$ & $\begin{array}{l}130 \\
(36.9) \\
\end{array}$ & $\begin{array}{l}157 \\
(44.6) \\
\end{array}$ & $\begin{array}{l}30 \\
(8.5)\end{array}$ & 2.52 & .788 \\
\hline My workstation design is suitable for my work in the library & $\begin{array}{l}48 \\
(13.6)\end{array}$ & $\begin{array}{l}120 \\
(34.1)\end{array}$ & $\begin{array}{l}158 \\
(44.9)\end{array}$ & $\begin{array}{l}26 \\
(7.4)\end{array}$ & 2.46 & .819 \\
\hline $\begin{array}{l}\text { My computer workstation furniture is flexible and suitable enough for } \\
\text { me to adjust, rearrange or reorganized my work }\end{array}$ & $\begin{array}{l}47 \\
(13.4)\end{array}$ & $\begin{array}{l}140 \\
(39.8)\end{array}$ & $\begin{array}{l}133 \\
(37.8)\end{array}$ & $\begin{array}{l}32 \\
(9.1)\end{array}$ & 2.43 & .834 \\
\hline $\begin{array}{l}\text { The backrest of my chair adequately supports my lower back as I } \\
\text { work }\end{array}$ & $\begin{array}{l}61 \\
(17.3)\end{array}$ & $\begin{array}{l}109 \\
(31.0)\end{array}$ & $\begin{array}{l}151 \\
(42.9)\end{array}$ & $\begin{array}{l}31 \\
(8.8)\end{array}$ & 2.43 & .878 \\
\hline I am easily accessed from my colleague's workstation & $\begin{array}{l}57 \\
(16.2)\end{array}$ & $\begin{array}{l}127 \\
(36.1)\end{array}$ & $\begin{array}{l}136 \\
(38.6)\end{array}$ & $\begin{array}{l}32 \\
(9.1)\end{array}$ & 2.41 & .865 \\
\hline $\begin{array}{l}\text { My workstation and equipment have sufficient adjustability that } \\
\text { ensures a healthy working posture }\end{array}$ & $\begin{array}{l}49 \\
(13.9)\end{array}$ & $\begin{array}{l}141 \\
(40.1)\end{array}$ & $\begin{array}{l}141 \\
(40.1)\end{array}$ & $\begin{array}{l}21 \\
(6.0)\end{array}$ & 2.38 & .797 \\
\hline My chairs are adjustable to fit my workstation & $\begin{array}{l}58 \\
(16.5)\end{array}$ & $\begin{array}{l}137 \\
(38.9)\end{array}$ & $\begin{array}{l}128 \\
(36.4)\end{array}$ & $\begin{array}{l}29 \\
(8.2)\end{array}$ & 2.36 & .853 \\
\hline $\begin{array}{l}\text { My workstation design is adequately equipped for my typical office } \\
\text { needs }\end{array}$ & $\begin{array}{l}59 \\
(16.8) \\
\end{array}$ & $\begin{array}{l}138 \\
(39.2)\end{array}$ & $\begin{array}{l}130 \\
(36.9) \\
\end{array}$ & $\begin{array}{l}25 \\
(7.1)\end{array}$ & 2.34 & .840 \\
\hline
\end{tabular}

Table 3 revealed the opinions of the respondents on the suitability of computer workstation and equipment designs on librarian's job satisfaction. Factors such as: satisfactory workstation height in relation to 
posture and viewing had a mean score of 2.69 with $54.8 \%$ of the respondents concurring with the statement. This was followed by workstation is designed to ensure that my wrist and hands do not rest on sharp or hard edges with a mean score of 2.55 with $43.5 \%$ of the respondents agreeing to the statement. Further, large computer workstation designed for work received a mean score of 2.54 with $44.6 \%$ of the respondents consenting on the statement. Comfortable workstation that supports my work posture (sitting/standing) attracted a mean score of 2.54 with $44.6 \%$ of the respondents agreeing to the statement. Sufficient room between the top of thighs and computer table showed a mean score of 2.54 as is evidenced by $46.9 \%$ of the respondents who accepted the statement. All these factors were considered as significant to job satisfaction for the librarians in the Federal and State University libraries in Southern Nigeria.

These findings are comparable with the findings of Korhonen et al. (2003) and Miller (2006) who affirmed that the set-up of a (computer) workstation should allow the user to adopt optimal working postures and, at the same time, allow the one some freedom of movement. As has been pointed out by De Lange et al. (2002) and Sluiter et al. (2003), poor workstation designs could decrease work performance as well as create negative health outcomes such as chronic fatigue, burnout and musculoskeletal disorders. It is based on this that Aghazadeh (1996) concluded that workstation designs significantly affect working posture which, in turn, contributes to physical health symptoms.

Research Question 2 asked: "How could work posture conditions (sitting or standing) have influence on job satisfaction of librarians?

Table 4: Posture conditions (sitting or standing) and job satisfaction of the Librarians

\begin{tabular}{|c|c|c|c|c|c|c|}
\hline STATEMENT & $\begin{array}{l}\text { SD } \\
(\%)\end{array}$ & $\begin{array}{l}\text { D } \\
(\%)\end{array}$ & $\begin{array}{l}\mathbf{A} \\
(\%)\end{array}$ & $\begin{array}{l}\text { SA } \\
(\%)\end{array}$ & Mean & SD \\
\hline There are enough space/room for my legs and feet & $\begin{array}{l}19 \\
(5.4)\end{array}$ & $\begin{array}{l}53 \\
(15.1)\end{array}$ & $\begin{array}{l}210 \\
(59.7)\end{array}$ & $\begin{array}{l}70 \\
(19.9)\end{array}$ & 2.94 & .751 \\
\hline $\begin{array}{l}\text { My work involves a lot of working in the same physical } \\
\text { position }\end{array}$ & $\begin{array}{l}15 \\
(4.3)\end{array}$ & $\begin{array}{l}56 \\
(15.9)\end{array}$ & $\begin{array}{l}221 \\
(62.8)\end{array}$ & $\begin{array}{l}60 \\
(17.0)\end{array}$ & 2.93 & .704 \\
\hline My lower back support is very adequate & $\begin{array}{l}21 \\
(6.0)\end{array}$ & $\begin{array}{l}67 \\
(19.0)\end{array}$ & $\begin{array}{l}194 \\
(55.1)\end{array}$ & $\begin{array}{l}70 \\
(19.9)\end{array}$ & 2.89 & .786 \\
\hline $\begin{array}{l}\text { The height of my workstation is satisfactory in relation to my } \\
\text { posture (sitting or standing) }\end{array}$ & $\begin{array}{l}29 \\
(8.2)\end{array}$ & $\begin{array}{l}78 \\
(22.2)\end{array}$ & $\begin{array}{l}194 \\
(55.1)\end{array}$ & $\begin{array}{l}51 \\
(14.5)\end{array}$ & 2.76 & .800 \\
\hline $\begin{array}{l}\text { My work involves lengthy sitting working in the same position } \\
\text { for a long period of time }\end{array}$ & $\begin{array}{l}38 \\
(10.8)\end{array}$ & $\begin{array}{l}74 \\
(21.0)\end{array}$ & $\begin{array}{l}182 \\
(51.7)\end{array}$ & $\begin{array}{l}58 \\
(16.5)\end{array}$ & 2.74 & .861 \\
\hline My chair is not a source of stress to me & $\begin{array}{l}27 \\
(7.7)\end{array}$ & $\begin{array}{l}95 \\
(27.0)\end{array}$ & $\begin{array}{l}177 \\
(50.3)\end{array}$ & $\begin{array}{l}53 \\
(15.1) \\
\end{array}$ & 2.73 & .809 \\
\hline I spend a lengthy period of working time at my workstation & $\begin{array}{l}22 \\
(6.3)\end{array}$ & $\begin{array}{l}107 \\
(30.4)\end{array}$ & $\begin{array}{l}166 \\
(47.2)\end{array}$ & $\begin{array}{l}57 \\
(16.2)\end{array}$ & 2.73 & .804 \\
\hline $\begin{array}{l}\text { The position of my workstation equipment allows for } \\
\text { satisfactory posture ( } \text { sitting or standing) }\end{array}$ & $\begin{array}{l}44 \\
(12.5)\end{array}$ & $\begin{array}{l}80 \\
(22.7)\end{array}$ & $\begin{array}{l}172 \\
(48.9)\end{array}$ & $\begin{array}{l}56 \\
(15.9)\end{array}$ & 2.68 & .887 \\
\hline I spend lengthy periods of working in the same position & $\begin{array}{l}31 \\
(8.8)\end{array}$ & $\begin{array}{l}106 \\
(30.1)\end{array}$ & $\begin{array}{l}172 \\
(48.9)\end{array}$ & $\begin{array}{l}43 \\
(12.2)\end{array}$ & 2.64 & .807 \\
\hline $\begin{array}{l}\text { My workstation is equipped to allow me to adopt correct } \\
\text { postures while working }\end{array}$ & $\begin{array}{l}34 \\
(9.7)\end{array}$ & $\begin{array}{l}115 \\
(32.7)\end{array}$ & $\begin{array}{l}165 \\
(46.9)\end{array}$ & $\begin{array}{l}38 \\
(10.8)\end{array}$ & 2.59 & .808 \\
\hline My chair allows me to place my feet flat on the floor & $\begin{array}{l}35 \\
(9.9)\end{array}$ & $\begin{array}{l}118 \\
(33.5)\end{array}$ & $\begin{array}{l}163 \\
(46.3)\end{array}$ & $\begin{array}{l}36 \\
(10.2)\end{array}$ & 2.57 & .807 \\
\hline My work requires repetitive movements & $\begin{array}{l}41 \\
(11.6)\end{array}$ & $\begin{array}{l}119 \\
(33.8)\end{array}$ & $\begin{array}{l}158 \\
(44.9)\end{array}$ & $\begin{array}{l}34 \\
(9.7)\end{array}$ & 2.53 & .823 \\
\hline The height of my worktable is adjustable for my posture & $\begin{array}{l}48 \\
(13.6)\end{array}$ & $\begin{array}{l}120 \\
(34.1)\end{array}$ & $\begin{array}{l}139 \\
(39.5)\end{array}$ & $\begin{array}{l}45 \\
(12.8)\end{array}$ & 2.51 & .883 \\
\hline $\begin{array}{l}\text { I do not have adequate posture support to my back, legs and } \\
\text { feet }\end{array}$ & $\begin{array}{l}50 \\
(14.2)\end{array}$ & $\begin{array}{l}136 \\
(38.6)\end{array}$ & $\begin{array}{l}124 \\
(35.2)\end{array}$ & $\begin{array}{l}42 \\
(11.9)\end{array}$ & 2.45 & .879 \\
\hline My work involves a lot of bending down regularly & $\begin{array}{l}46 \\
(13.1)\end{array}$ & $\begin{array}{l}163 \\
(46.3)\end{array}$ & $\begin{array}{l}108 \\
(30.7)\end{array}$ & $\begin{array}{l}35 \\
(9.9)\end{array}$ & 2.38 & .835 \\
\hline My work requires a lot of standing, daily & $\begin{array}{l}69 \\
(19.6)\end{array}$ & $\begin{array}{l}165 \\
(46.9)\end{array}$ & $\begin{array}{l}95 \\
(27.0)\end{array}$ & $\begin{array}{l}23 \\
(6.5)\end{array}$ & 2.20 & .829 \\
\hline
\end{tabular}

Table 4 revealed the agreement of the respondents regarding work posture condition as follows: having enough space/room for my legs and feet had a mean score of 2.94 with $59.7 \%$ of the respondents agreeing with this statement. This was followed by work involves a lot of working in the same physical position with a mean score of 2.93 showing $62.8 \%$ of the respondents concurring with the statement. Further, lower back support is very adequate had a mean score of 2.89 as demonstrated by $55.1 \%$ consenting with the statement. Finally, height of my workstation is satisfactory in relation to my posture received a mean score of 2.76 as perceived by $55.1 \%$ of the respondents accepting the statement. All these factors were considered as significant to job satisfaction for the librarians in the Federal and State University libraries in Southern Nigeria.

The study revealed that the respondents $(62.8 \%)$ agreed that their work requires working in the same physical position which could lead to the development some physical/musculoskeletal disorders. This finding 
corroborates that of Ansari et al. (2013) who discovered in their study, evidence of musculoskeletal disorders among the workers due to prolonged standing (working in the same position). Zander, King and Ezenwa (2004) also found in their study that prolonged standing transfers the load of upper body to the lower part which, in turn, results in lower back pains. Similarly, Fraser (2009) attested that there is no denying of the fact that the regular variation between sitting, standing and walking is vital as regards work posture. Forty five (45\%) of the respondents also affirmed that their work requires repetitive movements and this is a major determinant of musculoskeletal and vascular health. This also is in line with the observation of Akhahowa (2007) who have noted that poor work processes; environment and unsuitable working conditions could cause or aggravate conditions referred to as Carpel Tunnel Syndrome, Tenosynovitis, Repetitive Strain Injury (RSI) or Repetitive Motion Injury.

Testing of the Hypothesis

Pearson Product Moment Correlation (PPMC) analysis was employed in testing hypotheses one and two. The null hypotheses were tested at 0.05 significance level.

Hypothesis One: There is no significant relationship between workstation and equipment designs and job satisfaction of librarians.

Table 5: Relationship between suitability of workstation and equipment designs and job satisfaction of the librarians

\begin{tabular}{|l|l|l|l|l|l|l|}
\hline Variables & N & Mean & Std. Deviation & R & Sig. & Remark \\
\hline Job Satisfaction & 352 & 2.70 & 0.43 & 0.46 & .000 & Significant \\
\cline { 1 - 5 } $\begin{array}{l}\text { Suitability of workstation and equipment } \\
\text { designs }\end{array}$ & 352 & 2.48 & 0.56 & & \\
\hline
\end{tabular}

A summary of data on the test of relationship between job satisfaction and workstation and equipment designs is presented in table 5. As is revealed in the table, there is a significant positive relationship between job satisfaction and workstation and equipment designs in the Federal and State University libraries in Southern Nigeria $(\mathrm{r}=0.46, \mathrm{P}<0.05)$. The null hypothesis is therefore rejected as there is no sufficient evidence to accept it. This positive relationship implied that the more workstation and equipment design are suitable, the more the librarians will achieve job satisfaction.

Hypotheses Two: There is no significant relationship between the condition of work posture (sitting or standing) designs of librarians and the job satisfaction of librarians.

Table 6: Relationship between the conditions of work posture (sitting or standing) conditions of librarians and job satisfaction of the librarians

\begin{tabular}{|l|l|l|l|l|l|l|}
\hline Variables & $\mathrm{N}$ & Mean & Std. Deviation & $\mathrm{R}$ & Sig. & Remark \\
\hline Job Satisfaction & 352 & 2.70 & 0.43 & 0.15 & .005 & Significant \\
\hline Work posture condition & 352 & 2.64 & 0.38 & & & \\
\hline
\end{tabular}

Table 6 shows a significant positive relationship between condition of work posture (sitting or standing) of librarians and their job satisfaction $(\mathrm{r}=0.15, \mathrm{P}<0.05)$. The null hypothesis is therefore rejected as there is no sufficient evidence to accept it. The result here implies that adequate work posture could increase the job satisfaction of the library workforce in the Federal and State University libraries in Southern Nigeria.

\section{Conclusion and Recommendations}

The goal of this study was to find out the influence of suitability of workstation and equipment designs and the work posture ergonomics on job satisfaction of librarians in the Federal and State University libraries in Southern Nigeria. This study has revealed that the importance of job satisfaction can hardly be over emphasized in that it seriously affects organizational behavior and the achievement of organizational goal. This study has revealed that suitable workstation and equipment designs as well as condition of work posture are aspects of ergonomic factors that contributed significantly in attaining a higher level of job satisfaction for the librarians in the Federal and State Universities in Southern Nigeria.

In the light of the adverse effects of neglecting ergonomic principles in the designing of workstations and equipment at the workplace on job satisfaction, the resultant decrease in performance and production, and the numerous health effects that could result from poor ergonomics, this study recommends that there should be a collaboration between the University and Library management; in introducing and implementing ergonomic measures that would involve the set-up of adequate and healthy workstation equipment that would allow the users to adopt optimal working postures suitable for a greater job satisfaction of the library workforce and expected higher job performance and organizational success 


\section{References}

[1]. Adeyemi, A. O. (2010). ICT facilities: Ergonomics effects on academic library staff. Library Philosophy and Practice, 1-5. http://digitalcommons.unl.edu/cgi/viewcontent.cgi?article=1351\&context=libphilprac Retrieved January 2014

[2]. Akhahowa, A. E. (2007). Occupational overuse syndrome (OOS): a recurring problem in the computer industry of industrially developing countries (IDCs). A case study at University of Benin, Benin City, Nigeria. HFESA Journal, Ergonomics Australia, vol. 21(3).

[3]. Ajala, E. M. (2012). The influence of workplace environment on workers' welfare, performance and productivity. The African Symposium: An online journal of the African Educational Research Network.

[4]. Ansari, N. A., Shende, P. N., Sheikh, M. J. \& Vaidya, R. D. (2013). Study and justification of body postures of workers working In SSI by Using Reba. International Journal of Engineering and Advanced Technology (IJEAT), 2(3), 505-509. http://www.ijeat.org/attachments/File/v2i3/C1199022313.pdf Retrieved November 2013

[5]. Aghazadeh, L. H. A.(1996). Risk factors and their interactions in VDT workstation systems. In: Proceedings of the Human Factors and Ergonomics Society 40th Annual Meeting.Santa Monica, CA, USA: Human Factors and Ergonomics Society, 637-41.

[6]. Chandra, A. M., Ghosh, S., Barman, S., \& Chakravarti, D. P. (2009). Ergonomics issues in academic libraries in Kolkata, West Bangal: a pilot study. Library Philosophy and Practice. http://www.webpages.uidaho.edu/ mbolin/chandra-ghosh.pdf Retrieved May 2014

[7]. Chandrasekar, K. (2011).Workplace environment and its impact on organizational performance in public sector organizational. International Journal of Enterprise Computing and Business Systems. http://www.ijecbs.com/January2011/N4Jan2011.pdf Retrieved May 2014

[8]. De Croon, E.M., Sluiter, J.K., Kuijer, P.P.F.M \& Frings-Dresen, M.H.W.(2005). The effect of office concepts on worker health and performance: A Systematic review of the literature. Ergonomics, 48, 119-134.

[9]. De Lange, A. H., Tarris, T. W., Kompier, M. A. J., Houtman, I. L. D., \& Bonger, P. M. (2002).

[10]. Effects of stable and changing demand-control histories on worker health. Scand. J. Work Environ. Health, 28, 94-108.

[11]. Dempsey, P.G., McGorry, R.W., \& O'Brien, N.V. (2004). The effects of work height, work piece orientation, gender and screwdriver type on productivity and wrist deviation.

[12]. Int. J. Ind. Ergon. 33, 339-346.

[13]. DiLouie, C. (2004). "Personal control: Boosting productivity, energy savings," Lighting $\quad$ Controls Association.

[14]. http://lightingcontrolsassociation.org/personal-control-boosting-productivity-energy-saving Retrieved March 2014

[15]. Dole, C. and Schroeder, R. G. (2001). The impact of various factors on the personality, job satisfaction, and turnover intentions of professional accountants. Manage Auditing, 16 (4), 234-245.

[16]. Flanagan, N. A. and Flanagan, T. J. (2002). An analysis of the relationship between job $\quad$ satisfaction $\quad$ and $\quad$ job stress in correctional nurses. Research in Nursing and Health 25(4), 282-294.

[17]. Fraser, C. (2009).Computer workstations: design and adjustment revised by OH\&S Unit. http://www.google.ci/url? sa=t\&rct=i\&q=\&esrc=s\&source=web\&cd=1\&cad=rja\&ved=0CCsQFjAA\&url=http\%3A\%2F\%2Fwww.u q.edu.au\%2Fohs\%2Fpdfs\%2Fcomputerworkstations.pdf\&ei=G7ReUs6nGuO60QXDloCYDw\&usg=AFQjCNGYRj8vryiE bqQsXt DCY12-rHT0w\&bvm=bv.54176721,d.d2k Retrieved March 2014

[18]. Gazioglu, S. and Tansel, A. (2002). Job satisfaction in Britain: Individual and job-related factors.

[19]. Economic Research Centre Working Papers in Economics 03/03, Ankara available at:

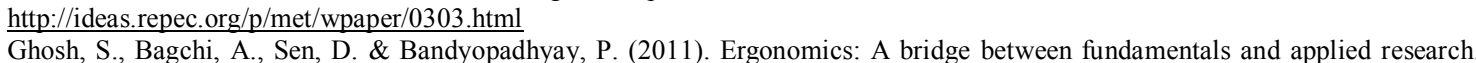

[21]. Human Factors and Ergonomics society of Australia, (2006).a

[22]. Korhonen, T., Ketola, R., Toivonen, R., Luukkonen, R., Häkkänen, M. \& Viikari-Juntur, E., (2003).

[23]. Work related and individual predictors for incident neck pain among office employees working with video display units. Occup. Environ Med., 60, 475-482.

[24]. Lafond, D., Champagne, A., Descarreaux, M., Dubois, J-B., Prado, J. M \& Duarte, M. (2009).

[25]. "Postural control during prolonged standing in persons with chronic low back pain," Gait \& Posture, 29, 421-427.

[26]. Lacsamana, M. (2002). Library ergonomics: A case study of the cataloging workstations of selected universities in the Philippines. B.L.I.S. undergraduate thesis, University of the Philippines Diliman, Institute of Library and Information Science.

[27]. Lee, S. Y. and Brand, G. L. (2005). Effects of control over office workspace on perceptions of the work environment and work outcomes. Journal of Environmental Psychology, 25(3), 323-333.

[28]. Miller, H. (2007). It's All About Me: The benefits of personal control at work research summary

[29]. "Worker Types, Worker Wants, Worker Comfort." 1-8.

[30]. http://www.hermanmiller.com/MarketFacingTech/hmc/research_summaries/pdfs/wp Personal_Control.pdf Retrieved April, 2014

[31]. Miles, A.K. (2000). The ergonomics and organizational stress relationship. PhD thesis, Florida State

[32]. University School of Business, micro. 9994574.

[33]. O'Neill, R. (2005) Standing problem. Hazards magazine. Centrepage http://www.hazards.org/standing/ Retrieved May 2012

[34]. Office Ergonomics Handbook, (2008), $5^{\text {th }}$ ed. Occupational health clinics for Ontario workers Inc. 1- 57.

[35]. https://www.ona.org/documents/File/healthandsafety/msd_ergonomics/OfficeErgonomicsHandbook_OHCOW.pdf http://www.opseu.org/hands/Ergonomicshandbook.pdf Retrieved March 2014

[36]. Sluiter, K. de Croon, E. M, Meijman, T. F. \& Frings-Dresen, M. H. W. (2003). Need for recovery from work related fatigue and its role in the development and prediction of subjective health complaints. Occup. Environ. Med., 60, 62-70.

[37]. Timoteo-Afinidad, C. B. (2010). Workstation and workspace ergonomics in Philippine libraries: an emerging priority. Journal of Philippine Librarianship, 30 (1) 21-44.

[38]. Uwaifo, S. O. (2008) "Nigerian library staff and their perceptions of health risks posed by using computer-based systems in University libraries", Program: electronic library and information systems, 42(1), $68-75$.

[39]. Washington State Department of Labor and Industries (2002). Office ergonomics: Practical solutions for a safer workplace. http://www.lni.wa.gov/IPUB/417-133-000.pdf Retrieved January 2014

[40]. WorkSafeNB (2010). Office Ergonomics: Guidelines for preventing musculoskeletal injuries. 1-16.

[41]. Zander, J. E., King, P. M. \& Ezenwa, B. N. (2004). "Influence of flooring conditions on lower leg volume following prolonged standing," International Journal of Industrial Ergonomics, 34, 279-288. 